\title{
TINGKAT PENGETAHUAN PASIEN GASTRITIS PADA PENYEBAB GASTRITIS RELAPSE
}

\author{
Fahruddin $^{1}$, Andalia Roza ${ }^{2}$, Putri Wulandini ${ }^{3}$ \\ ${ }^{1}$ RSUD Arifin Achmad Provinsi Riau \\ fahrudin@gmail.com
}

${ }^{2}$ Fakultas Kedokteran dan Ilmu Kesehatan Universitas Abdurrab andalia.roza@univrab.ac.id

${ }^{3}$ Fakultas Kedokteran dan Ilmu Kesehatan Universitas Abdurrab Putri.wulandini@univrab.ac.id

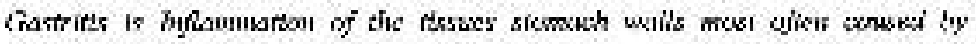

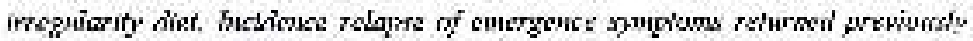

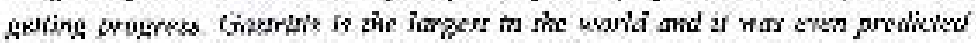

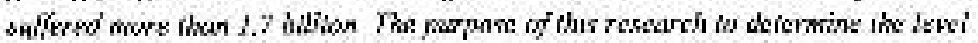

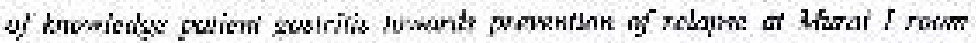

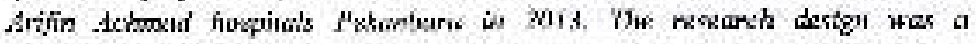

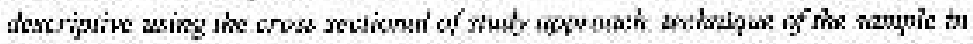

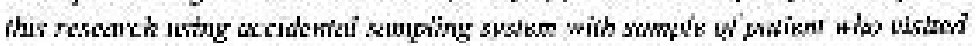

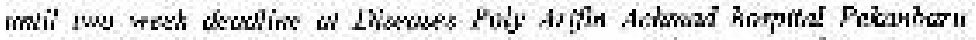

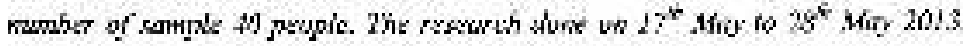

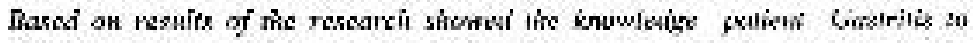

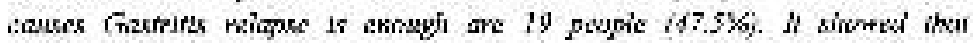

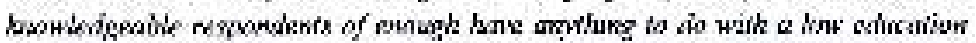

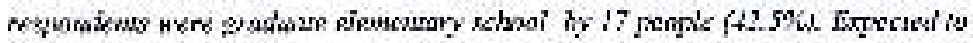

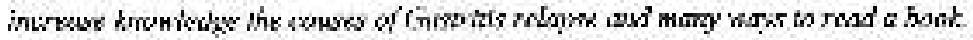

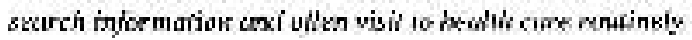

\section{Abstract}

Keyword:Knowledge, Gastritis, Relapse

$$
\text { Abstrak }
$$

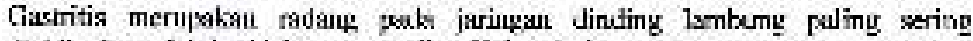

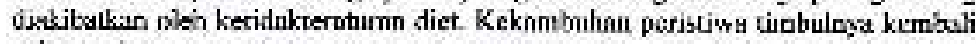

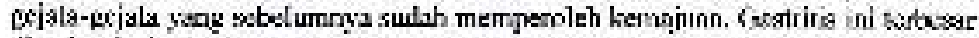

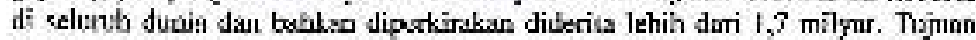
penemlitian ini adalah nntuk menepctalwa Itujhat J'cugelaluan P'asien Gassrilix

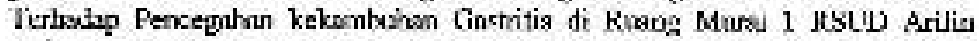

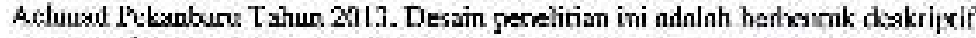

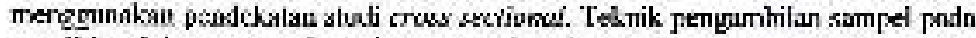

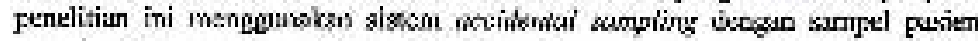

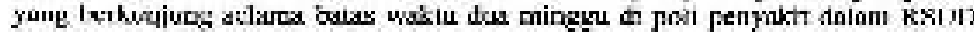

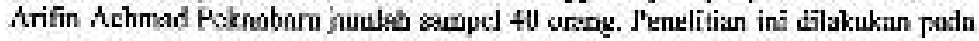

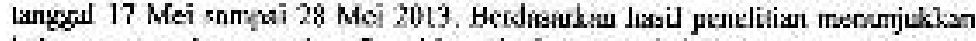

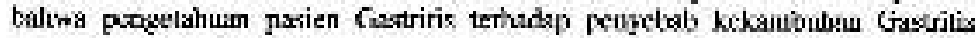

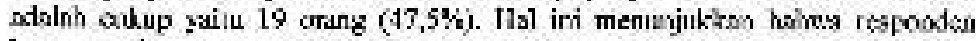

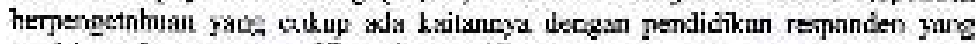

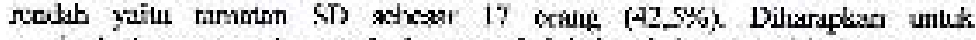

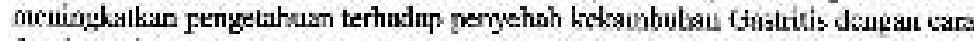

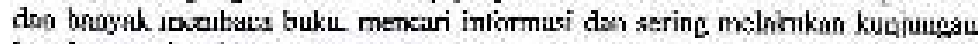
kepeloymmon bescliatas açara sulia. 


\section{PENDAHULUAN}

Dalam kehidupan sehari-hari, sering kita dengar banyak orang mengeluh rasa tidak nyaman pada perut bagian atas, misalnya pada perut selalu penuh, mual, perasaan panas, rasa pedih sebelum dan sesudah makan. Salah satu penelitian yang mempelajari kemungkinan kelainan dalam jalan makan yang dihubungkan dengan keluhan seperti tersebut diatas. Broussais (2006) menyelidiki perubahanperubahan anatomis dari lambung dan usus halus. Pada otopsi ditemukan gastritis yang lanjut sebagai dasar kelainan patogenik (Hadi, 2007).

Gastritis merupakan radang pada jaringan dinding lambung paling sering diakibatkan oleh ketidakteraturan diet. Misalnya makan terlalu banyak, terlalu cepat, makan-makanan terlalu banyak bumbu atau makanan yang terinfeksi penyebab yang lain termasuk alcohol, aspirin, refluk empedu atau therapy radiasi (Brunner \& Suddarth, 2008).

Pola makan yang baik terdiri dari frekuensi makanan, jenis makanan, pola makan yang teratur merupakan salah satu dari penatalaksanaan gastritis dan juga merupakan tindakan preventif dalam mencegah kekambuhan gastritis. Penyembuhan gastritis membutuhkan pengaturan makanan sebagai upaya untuk memperbaiki kondisi pencernaan (Uripi, 2009).

Kekambuhan adalah peristiwa timbulnya kembali gejala - gejala yang sebelumnya sudah memperoleh kemajuan (Stuart dan Laraia, 2008).

Menurut Murphy (2007), Faktor resiko untuk kambuh adalah: Faktor resiko kesehatan, seperti gangguan sebab dan akibat berfikir, gangguan proses informasi, gizi buruk, kurang tidur, kurang olahraga, keletihan. Faktor resiko lingkungan, seperti: kesulitan keuangan, kesulitan tempat tinggal, perubahan yang menimbulkan stress dalam peristiwa kehidupannya, ketrampilan kerja yang buruk, ketidakmampuan mempertahankan pekerjaan, tidak memiliki transportasi, ketrampilan sosial yang buruk, kesulitan interpersonal. Faktor resiko perilaku dan emosional seperti : Tidak ada control, Perubahan mood, Pengobatan dan penatalaksanaan gejala yang buruk.

Keluhan Gastritis merupakan suatu keadaan yang sering dan banyak dijumpai dalam kehidupan sehari-hari. Tidak jarang kita jumpai penderita Gastritis kronis selama bertahun-tahun pindah dari satu dokter ke dokter yang lain untuk mengobati keluhan Gastritis tersebut. Berbagai obat-obatan penekan asam lambung sudah pernah diminum seperti antasid, namun keluhan selalu datang silih berganti. Keluhan yang berkepanjangan dalam menyembuhkan Gastritis ini dapat menimbulkan stress (Budiana, 2006).

Budiana (2006), mengatakan bahwa Gastritis ini terbesar di seluruh dunia dan bahkan diperkirakan diderita lebih dari 1,7 milyar. Pada negara yang sedang berkembang infeksi diperoleh pada usia dini dan pada negara maju sebagian besar dijumpai pada usia tua. Angka kejadian infeksi berulang Gastritis Helicobacter Pylory pada beberapa daerah di Indonesia menunjukkan data yang cukup tinggi. Menurut Maulidiyah dan Unun (2006), di Kota Surabaya angka kejadian kekambuhan gastritis sebesar $31,2 \%$, Denpasar 46\%, sedangkan di Medan angka kejadian infeksi cukup tinggi sebesar 91,6\%. Adanya penemuan infeksi Helicobacter Pylory ini mungkin berdampak pada tingginya kejadian Gastritis. Faktor etiologi Gastritis dan kekambuhan lainnya adalah asupan alkohol berlebihan 
(20\%), merokok (5\%), makanan berbumbu (15\%), obat-obatan 18\%) dan terapi radiasi $(2 \%)$ (Herlan, 2006).

Dari hasil penelitian para pakar, didapatkan jumlah penderita Gastritis antara pria dan wanita, ternyata Gastritis lebih banyak pada wanita dan dapat menyerang sejak usia dewasa muda hingga lanjut usia. Di Inggris 6-20\% menderita Gastritis pada usia 55 tahun dengan prevelensi $22 \%$ insiden total untuk segala umur pada tahun 1988 adalah 16 kasus/1000 pada kelompok umur 45-64 tahun. Insiden sepanjang usia untuk Gastritis adalah 10\% (Harun Riyanto, 2008). kekambuhan berulang gastritis di Poli Penyakit Dalam RSUD Arifin Achmad Pekanbaru sebanyak 4284 selama satu tahun.

Data awal di poli penyakit Dalam RSUD Arifin Achmad Pekanbaru tahun 2012 Berdasarkan hasil survey yang dilakukan peneliti selama satu hari di Poli Penyakit Dalam RSUD Arifin Achmad didapatkan hasil dengan jumlah responden 10 orang dengan hasil data 4 orang yang berpengetahuan kurang, 3 orang berpengetahuan cukup dan 3 orang berpengetahuan baik. Berdasarkan latar belakang diatas peneliti sangat tertarik untuk dibuat penelitian dengan judul Tingkat Pengetahuan Pasien Gastritis Terhadap Pencegahan Kekambuhan Gastritis. Tujuan Penelitian Untuk mengetahui Tingkat Pengetahuan Pasien Gastritis Terhadap Pencegahan kekambuhan Gastritis.

\section{METODA PENELITIAN}

Desain penelitian ini adalah berbentuk deskriptif menggunakan pendekatan studi cross sectional. Penelitian ini dilakukan poli penyakit dalam RSUD Arifin Achmad Pekanbaru. Penelitian ini dilakukan pada tanggal 17 Mei 2013 sampai 28 Mei 2013. Populasi dalam penelitian adalah keluarga pasien yang berkunjung ke poli penyakit dalam RSUD Arifin Achmad Pekanbaru, Dari diklat didapatkan jumlah dalam setahun 4284 dengan rata-rata kunjungan perbulan 357 responden. Pada penelitian ini pemilihan sampel accidental sampling. Seluruh pasen dalam batas waktu dua minggu yang berada di poli penyakit dalam RSUD Arifin Achmad Pekanbaru, sesuai dengan kriteria inklusi yang dibuat oleh 
peneliti:

1) Pasien yang bersedia sebagai responden dan tidak buta, tidak gangguan pendengaran dan tidak sakit.

2) Pasien gastritis.

\section{HASIL DAN PEMBAHASAN}

\section{A. Hasil Penelitian}

Pada bab ini akan diuraikan hasil penelitian tentang tingkat pengetahuan pasien gastritis terhadap penyebab kekambuhan gastritis di poli penyakit dalam di RSUD Arifin Achmad Pekanbaru. Penelitian ini dilaksanakan pada tanggal 17 mei sampai 28 mei 2013 di poli penyakit dalam RSUD arifin achmad pekanbaru. Analisa data Berdasarkan tabel diatas diketahui bahwa distribusi frekuensi karakteristik responden menurut umur terbanyak berada dalam rentang 41 sampai 60 tahun yaitu 15 orang $(37,5 \%)$, distribusi frekuensi karakteristik responden menurut jenis kelamin terbanyak adalah perempuan yaitu 27 orang $(67,5 \%)$. Dan terbanyak adalah IRT yaitu 15 orang $(37,5 \%)$. distribusi frekuensi karakteristik responden menurut pendidikan terbanyak adalah tamatan SD yaitu 17 orang $(42,5 \%)$.

Berdasarkan hasil penelitian menunjukkan bahwa distribusi frekuensi responden berdasarkan pengetahuan lansia tentang cara hidup sehat di Wilayah Kerja

Puskesmas Rumbai adalah sedang yaitu 19 orang $(47,5 \%)$. kekambuhan gastritis adalah cukup yaitu 19 orang

(47,5\%). berpengetahuan yang cukup ada kaitannya dengan pendidikan responden yang rendah yaitu tamatan SD sebesar 17 orang (42,5\%). Menurut machfoed (2005), seseorang

yang mampu mengungkapkan

informasi dengan benar maka bisa dikategorikan memiliki pengetahuan yang tinggi tentang objek tersebut.
Apabila seseorang hanya

mampu mengungkapkan sedikit informasi dari suatu objek maka dikategorikan memiliki pengetahuan rendah tentang variabel tersebut. Oleh karena itu dengan pengetahuan yang cukup begitu juga kurang akan meningkatkan resiko permasalahan kesehatan penderita gastritis, khususnya terkait

permasalahan tentang cara hidup sehat yang kurang baik, akan meningkatkan dampak resiko penyakit generatif bagi penderita gastritis, seperti hipertensi, DM, rematik, penyakit jantung dan stroke.

Sehingga penderita gastritis berpengetahuan yang cukup atau kurang berdampak pada perilaku kesehatan mereka yang kurang baik. Menurut Notoatmodjo (2003), perilaku kesehatan adalah suatu respon seseorang (organisme) terhadap stimulus atau objek yang berkaitan dengan sakit atau penyakit, sistem pelayanan kesehatan, makanan, dan minuman, serta lingkungan. Dari uraian diatas dapat disimpulkan bahwa perilaku kesehatan seseorang sangat dipengaruhi oleh pengetahuan suatu objek.

Menurut Nursalam (2003), pengetahuan merupakan suatu usaha yang mendasari seseorang untuk berpikir ilmiah. Pengetahuan itu sendiri dipengaruhi oleh sifat kepribadian, bakat, bawaan, intelegensi, pekerjaan, informasi, usia, pengalaman, pendidikan, lingkungan, agama, dan kebudayaan, sedangkan tingginya pengetahuan seseorang tergantung dasar pendidikan tersebut. Maka untuk meningkatkan pengetahuan harus meningkatkan jenjang pendidikan, sehingga dengan pendidikan tinggi sudah seharusnya mempunyai pengetahuan yang baik. Maka tercipta perilaku hidup sehat dan dapat meningkatkan derajat kesehatan melalui 
cara-cara hidup sehat, seperti olahraga, makanan bergizi, istirahat yang cukup dan memeriksa kesehatan secara rutin pada pelayanan kesehatan.

\section{KESIMPULAN}

Berdasarkan penelitian yang telah dilakukan mengenai tingkat pengetahuan pasien gastritis terhadap penyebab kekambuhan gastritis di poli penyakit dalam RSUD arifin achmad pekanbaru, terhadap 40 responden dapat disimpulkan bahwa hasil pengetahuan pasien gastritis terhadap penyebab kekambuan gastritis adalah cukup yaitu sebanyak 19 orang (50\%).

DAFTAR PUSTAKA

Arif. (2009). Keperawatan Medikal Bedah,

Jakarta. EGC.

Beruner \& Suddarth (2008).

Keperawatan Medikal

Bedah. Jakarta. EGC.

Budiman. (2009). Metodologi

Penelitian Psikologi, Jakarta:

Rieka Cipta.

Hadi. (2007). Prinsip-prisip Ilmu

Penyakit Dalam, Jakarta.s

EGC.

Herz \& Menvile (2006). Strees Lambung Anda, Jakarta: Arean.

Kunto, A. (2008). Konsep dan Penerapan Metodelogi Penelitian Edisi Pertama. Jakarta: Salemba Medika

Murphy. (2007). Keperawatan Medikal Bedah. Jakarta. EGC.

Nursalam. (2007). Konsep dan Penerapan Metodelogi Penelitian Ilmu Keperawatan : Pedoman Skripsi, Tesis, dan Instrumen Penelitian Keperawatan. Jakarta. Salembah Medika.

Notoatmodjo, Soekidjo (2007). Ilmu Kesehatan Masyarakat, Jakarta :
Rineka Cipta

Hidayat, A, Aziz, Alimul. 2007. Riset Keperawatan dan tekhnik penulisan ilmiah. Jakarta : Salemba Meduka.

Notoatmodjo, Soekidjo (2009). Metodologi Penelitian Kesehatan, Jakarta : Rineka Cipta.

Rianto, H. (2008). Buku Ajar Ilmu Penyakit Dalam, Jakarta: FKUI

Sudijono. (2008). Konsep Metodologi Penelitian Ilmu Keperawatan Edisi Pertama, Jakarta : Salemba Medika

Utomo. (2007). Apresiasi Penyakit Dalam, Jakarta : Rineka Cipta

Uripi. (2009). Gangguan Saluran Pencernaan Hepatitis, Jakarta: Puspa Swara

Hidayat, A, Aziz, Alimul. 2007. Metodologi Penelitian Tekhnik Analisis Data. Jakarta : Salemba Medika.

Machfoedz, Ircham. 2009. Metodologi Penelitian Bidang Kesehatan, Keperawatan,

Kebidana

n, Kedokteran. Yogyakarta : Fitmaya.

Nursalam,. et al. 2008. Konsep dan Penerapan Metodologi Penelitian Ilmu Keperawatan : Pedoman

Skripsi, Tesis dan Instrumen Penelitian Keperawatan. Jakarta : Salemba Medika

Sabri, Luknis, dan Sutanto Priyo Hastono. 2010. Statistik Kesehatan. Jakarta : Rajawali Pers. 